\title{
REINTERPRETATION OF ISTANBUL'S IMAGE THROUGH LIGHT MAPPING
}

\author{
Rana KUTLU \\ İstanbul Kültür University, Faculty of Art and Design, Istanbul \\ rana.guvenkaya@gmail.com \\ Banu MANAV \\ İstanbul Kültür University, Faculty of Art and Design, Istanbul \\ manav.banu@gmail.com
}

\begin{abstract}
In the present study, historical and contemporary masterpieces in Istanbul will be discussed and analyzed considering "lighting scheme" as a design tool in the "lighting master plan". The present image of the city will be analyzed together with the light mapping tool. It was intended to introduce a "conceptual lighting master plan" where a lighting vocabulary is introduced for both educational purpose and as a metaphor in line with the enormous historical background of Istanbul. The scheme can be an overview or road map of how lighting might be used to meet the various program requirements while it also enhances and entegrates with the architecture.Through the effective use of the lighting scheme, the unity and diversity in the history of the old city can be highlighted.
\end{abstract}

Keywords: Light Mapping, Visual Culture

\section{INTRODUCTION}

İstanbul is one of the most important cultural centers of the world. The city embraces two continents, one arm reaching out to Asia, the other to Europe.Through the city's heart, The Bosphourus strait, course the waters of the Black Sea, the sea of Marmara and The Golden Horn. İstanbul is the former capital of three successive empires-Roman, Byzantine and Ottoman. Today city honors and preserves the legacy of its past while looking forward to its modern future. The historical buildings; museums, churches, palaces, great mosques, bazaars and sights of natural beauty are Istanbul's variety and these architectural and natural beauties constitute environment and fascinate its visitors.

Also, lighting is a fascinating subject, which has physical, psychophysical and aesthetic aspects. Light and colour are two basic factors of human perception. Lighting of historical buildings and monuments plays an important part in the creation of urban lighting conditions. Lighting scheme can be used to emphasize the hierarchy and identity of masterpieces while city lighting plan can be designed with a zoning of the historical places on a light map. The color and lighting scheme can set a mood for the image of the city. Exterior lighting gives scope for new creativity, the opportunity to design in light and color on a scale that extends from distant view of a town to the close detail of the building facade.

In the study, historical and contemporary masterpieces in Istanbul will be discussed and analyzed considering "lighting scheme" as a design tool in the "lighting master plan". The present image of the city will be analyzed together with the light mapping tool. In the transformation and interpretation of the historical identity to the city silhouette, light can be used to formulate this idea. This statement will be discussed at various viewpoints in the specially selected historical places in Istanbul. 


\section{URBAN IDENTITY AND LIGHTENING}

The term of identity is commonly used in a number of disciplines concerned with the study of human behavior, conduct and societal structures in general. Lynch [1] defines identity as "the extent to which a person can recognize or recall a place as being distinct from other places". Like individuals, cities should have character and distinctions; like individuals, this flavour is made up of numerous characteristics, or identifiable elements [2],[3]. Urban spaces created through urban design come along as determining and guiding parameters with respect to urban identity [4]. Cities acquire an identity through the effects of the environment and their interaction. Especially, historical places are great importance because of reflecting the life styles of their era in spite of the monotonous view of city's general structure and because of having symbolic characteristics of the city so that they provide the region to be known by the others and present the wealth of beautiful views.

Lighting has physical, psychophysical and aesthetic aspects for human perception on urban identity. A renovated interest about light in the city has grown in the last few years. This due to a change in life style and way of living public spaces during the night. This interest for public in general, born in 80 's, was the base for social and architectural studies and for involving of lighting in urban studies. City lighting was seen more as functional and crime prevent lighting projects were based on "more lighting equals to more safety". Starting from this point of view, a misunderstanding on terms and definitions of outdoor lighting happens today.

Many cities worldwide are interested in the topic of nighttime urban planning. The purpose is clearly to enhance citizen safety, security, to support bussiness interests, to save energy and improve the city's nighttime ambience, while at the same time minimizening all aspects of light pollution. When urban centers are being considered the following issues become important:

- the provision of lighting that will ensure safety from moving vehicles for pedestrians

- the provision of lighting that is appropriate for the type and volume of the vehicular traffic

- the provision of lighting designs and equipment appropriate to the architectural scene and urban landscape

- the provision of lighting that will deter anti-social behaviour [5].

Lighting is highly visible and a positive nighttime image of the city can help enhance communication; social interaction, esthetical enhancing, visual comfort, safety and security. The goals of a city lightening plan are likely to be [6];

- to establish the city as a leader in sensitivity to its appereance and utility an night as well as in the day, and to insure recognition of its effective and efficient lighting of the public and private

- to create a greater sense of the vitality of the city at night, encouraging more frequent visits by residents and tourists

Urban lighting includes some basic factors in the field of lighting and urban space as; communication, esthetical enhancing, renewal of outdoor environment, urban renewal. These factors should be integrated with another one, that is essential. It is the notion of "environment" as system of relations between subject and his space. It depends on our sensitivity, it is the result of our perception of space, difference between light and shadow, colour, of planting, movements and other things.

Urban lighting and public lighting are, in fact, deeply different for the concept itself and for the way to face a lighting Project. Public lighting is seen more as functional lighting in outdoor environment, responding to technical parameters, while "urban lighting" is a 
multidisciplinaire concept. So in this study, urban lighting will be discussed at various view points in the specially selected historical places on the Bosphourus Strait.

\section{REINTERPRETATION OF ISTANBUL'S IMAGE THROUGH LIGHT MAPPING}

Urban lighting affects the nightscape of a city. Many cities in the world have embarked on similar schemes where lighting is included as an integral part of the city planning. Istanbul is one of these cities which has become a cultural melting pot where there is the remnants of history from Byzantine to today. There is a bridge between the past and the present, unvisible powers of light energy,color are carried through years and this power is hidden in various historical buildings. A lighting scheme need not address all areas or spaces. Especially Bosphorus Strait offers a delightful mixture of past and present.Therefore, in the study it is aimed that a conceptual lighting master plan for Bosphorus region is introduced and analyzed in line with the enormous historical background of Istanbul (Figure 1).
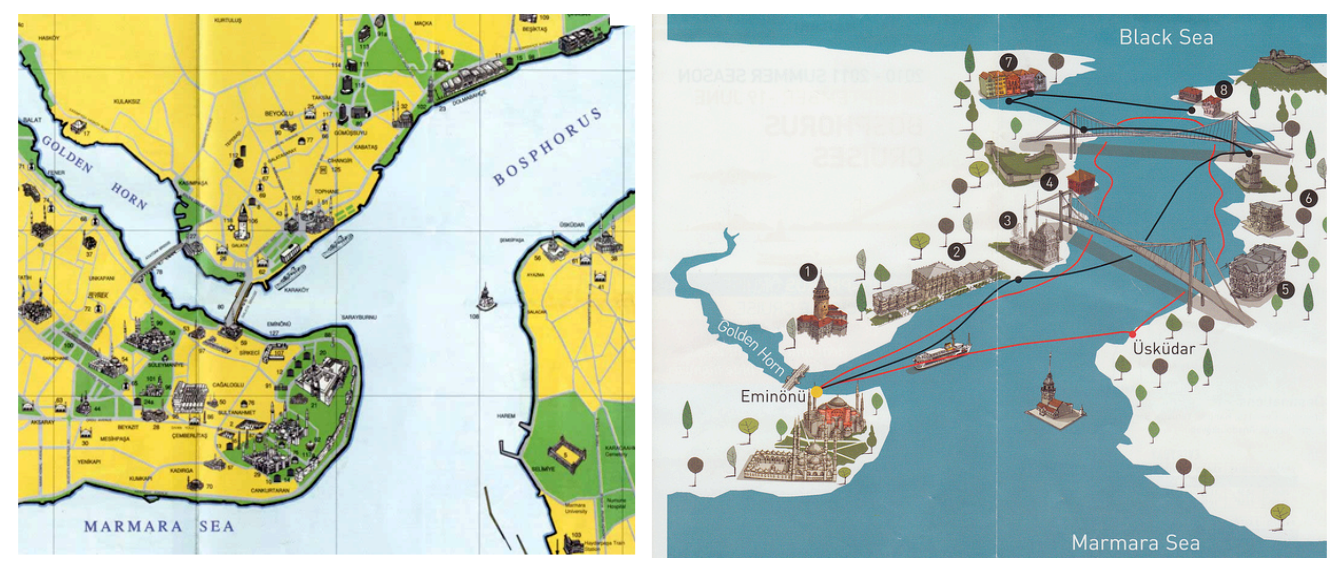

Figure 1.Historical Background of Istanbul

[http://www.turkeymaps.net/istanbul-tourist-map.html/istanbul-bosphorus-map]

The scheme can be an overview or road map of how lighting might be used to meet the various program requirements while it also enhances and entegrates with the architecture.Through the effective use of the lighting scheme, the unity and diversity in the history of the old city can be highlighted. The color of light can change from white to red and blue following the chronological order of the masterpieces in the city. There also can be a progression of the light level from the bright (symbolizing contemporary masterpieces) to the dark (symbolizing historical masterpieces). Lighting is an expression of civic pride, so lighting master plan is necessary, but individual, uncoordinated approaches are likely to bring negative results. Preparation of lighting master plan needs close interaction among the authorities, architecture, city planner, lighting designer and electrical consultant.

Architectural Features; It is necessary to study the historical background and architectural details. Historical peninsula, galata-pera presents historical heritage, Levent-Maslak region presents modern images to the visitors (Figure 2). Architectural features affect the city silhoutte, so while analysing the city, revealing basic architectural features is important. Historical silhoutte and modern silhoutte can be seen in figure 2. In such cases, these differerences must be evaluated perfectly. Silhouttes which take place at the certain view and within one sight, should be evaluated according to the lighting master plan of the city. 

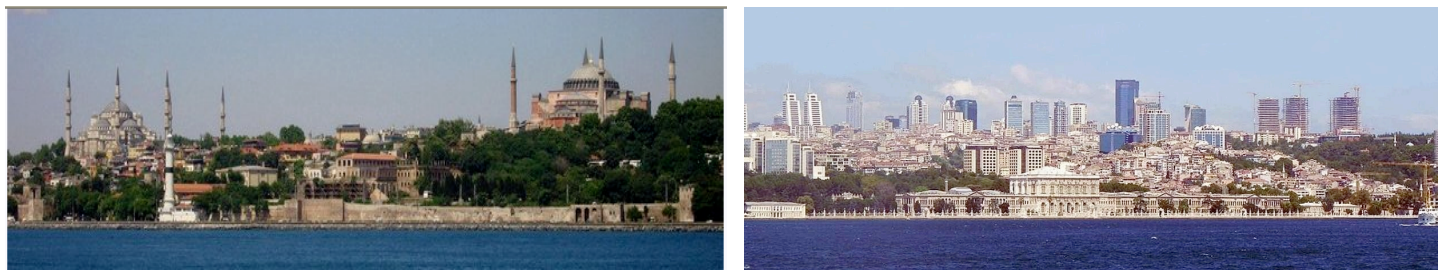

Figure 2. Architectural Features Affect Historical Silloutte and Modern Silloutte

This study deals with lighting design which displays a building as an object of interest and architectural merit because of its function or age. The art of floodlighting of such buildings usually depends upon illuminance variation to achieve its objectives. Floodlighting does not seek to reproduce a daylight appearance, but rather to show the structure in a different but recognizable and attractive way. To this end it is important to realize that when displaying a building designing shadow is also important. Shadows created can be as important as the illuminated areas, and therefore, in a way, the term floodlighting is in appropriate, since merely flooding a building with light produces a very uninteresting result.

Hierarchy; In case a great number of important buildings take place at the silhoutte, their effective images must be analyzed from the near and far viewpoints. To make the building or monument more interesting, artistic use of light and light,shade and shadow or colour difference is necessary. The lighting plan shall be in accordance to the architectural identity of the building, its location in the community and the view of those who own the building, should be undertaken before an attempt at external lighting of a building is made(Figure 3). This is particularly true with regard to the colour of the light to be employed.

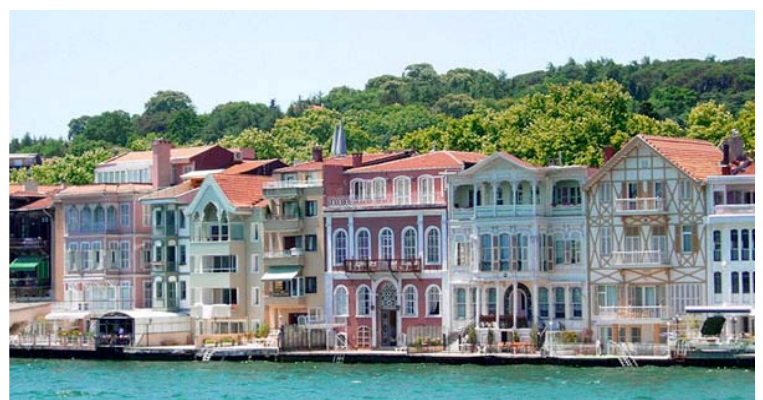

Figure 3. Traditional Waterfront Houses On The Bosphorus Strait, Istanbul

Symbols; Elements which identify, associate, make marks on the image of a city are important for the lighting master plan of a city. These elements might be historical, unique, original structures or modern structures. Galata Tower can be given as an example or Kiz Kulesi is one of the most romantic symbols of İstanbul, too (Figure 4).
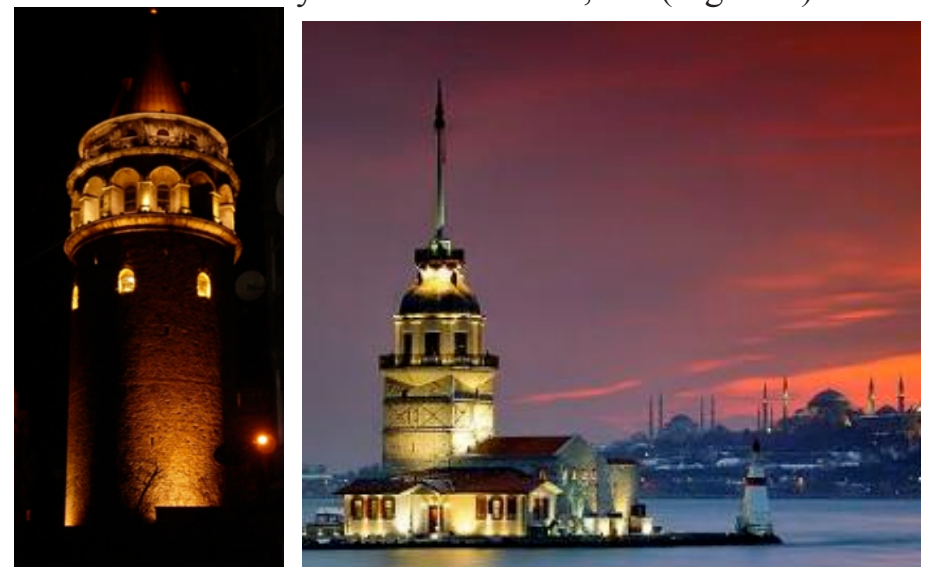

Figure 4. Symbols of the City- Galata Tower and Kiz Kulesi 
There is a temptation to use coloured light to obtain a dramatic effect. This can be very successful, but only in very specific and appropriate circumstances. In general, a building usually benefits from unifying effect of a single colour of light or, occasionally, a subtle change of colour with direction. It is the revealing power of the light that should be harnessed in the scheme's design. Light from a prominent direction can display a building very successfully by allowing the varying orientation of the building'surfaces to create the shadows necessary to reveal its features [7].

Viewing Points - Proximity; In outdoor and architectural lighting, viewing directions of the observers also has to be kept in mind for the lighting master plan. Viewing points for the visitors or people passing by should be known to decide the aiming directions of the luminaires, while eliminating the glare. Facades shall be illuminated in a way to overcome flatness and being uninteresting. As far as possible, the direction of the lighting should not be from the same direction as the main direction of view of people looking at it.

\section{CONCLUSION}

In this study, historical and contemporary masterpieces in Istanbul is discussed and analyzed considering "lighting scheme" as a design tool in the "lighting master plan". The present image of the city is analyzed together with the light mapping tool. In the transformation and interpretation of the historical identity to the city silhouette, light was used to formulate this idea. According to the results, there are three key factors to effective lighting on cities:

- Practical, feasible and functional. Lighting scheme must be sensitive to the character of the city and must address the needs of the city in a way that meets the city's objectives.

- Holistic design. Lighting scheme must include all the components of the outdoor urban environment, maximizing the value of the night lighting and minimizing all the potential adverse effects.

- Technically aware. There is no need to light everything all night or to light at the same level late at night as early in the night.

\section{REFERENCES}

[1] Lynch K (1981). A Theory of Good City Form, MIT Press, Cambridge.

[2] Oktay D (2002). The Quest For Urban İdentity İn The Changing Context Of The City Northern Cyprus, Cities 19: 261-271

[3] Thompson CW (2002). Urban Open Space İn The 21st Century, Landsc. Urban Plan. 60: 59-72.

[4] Lynch K (1960). The Image Of The City,The MIT Press, Cambridge.

[5] Cartier, J. (1998). Lumieres Sur la Ville-l'amenagement et la Ville Nocturne: De la Pratique Professionnelle A L' Usager, ANTPE, Ales, p:275

[6] Bordonaro, E., Aghemo,C., (2006). Urban Lighting= A Multidisciplinare Approach, Urban Nightscape 2006 Conference Proceedings

[7] Bean, R., (2004). Lighting: Interior And Exterior, Elsevier Architectural Press,p: 229 